сутки. Проведенными исследованиями установлено, что выпаивание пробиотического препарата «Энзимспорин» телятам, начиная с первых суток жизни по десятые в дозе 1 г и с 10-ых по 30-ые - по 2 г на одного теленка, а также дополнительное применение пробиотика «Лактоамиловорин-СП» в дозе 10 г на одно животное, начиная с первых суток после рождения по 30ые, способствуют увеличению содержания бифидо- и лактобактерий в 2,7 и 2,6 раза соответственно; снижению содержания бактерий группы кишечной палочки в 1,6 раза; снижению содержания грибов рода Candida в 1,6 раза.

A. Andreeva, G. Sultangazin, O. Altynbekov

\title{
EFFECT OF PROBIOTICS «ENZIMSPORIN» AND «LACTOAMILOVORIN-SP» ON THE MICROBIOCENOSIS OF CALVES IN EARLY POSTNATAL PERIOD
}

Key words: probiotics; newborn calves; intestinal microflora; formation of microbiocenosis.

Authors' personal details

1. Alfiya Andreeva, Doctor of Biological Sciences, Professor, Head of the Department of Infectious Diseases, Animal Hygiene and Veterinary Sanitary Inspection, Federal State Budgetary Educational Institution of Higher Education «Bashkir State Agrarian University», Ufa, ul. 50-letiya Oktyabrya, 34, e-mail: alfia andreeva@mail.ru.

2. Gazinur Sultangazin, Post-graduate student of the Infectious Diseases, Animal Hygiene and Veterinary Sanitary Inspection Department, Federal State Budgetary Educational Institution of Higher Education «Bashkir State Agrarian University», Ufa, ul. 50-letiya Oktyabrya, 34, e-mail: gazinursultangazin@mail.ru.

3. Oleg Altynbekov, Candidate of Biological Sciences, Senior Lecturer of the Infectious Diseases, Animal Hygiene and Veterinary Sanitary Inspection Department, Federal State Budgetary Educational Institution of Higher Education «Bashkir State Agrarian University», Ufa, ul. 50-letiya Oktyabrya, 34, e-mail: oleg 030291@mail.ru.

The advanced technology of rearing young animals employs microbiological additives, such as probiotics, to prevent gastrointestinal diseases. The technology is based on environmentally safe mechanisms for maintaining a high level of intestinal colonization resistance. The research aimed to study the dynamics of the intestinal microflora in newborn calves fed the probiotics «Enzimsporin» and «Lactoamilovorin-SP». The study's object was newborn calves fed a diet with probiotic supplements from birth to one month of age. The study involved five calf groups (one control group and four test groups) formed on the analog pair principle. Fecal samples were collected for bacteriological studies on the 1st day after introducing the probiotics and the 14th and 30th days. Calves were bottle-fed the probiotic supplement «Enzimsporin» during the first ten days of life at a dose of $1 \mathrm{~g}$ per animal, during the next 20 days at a dose of $2 \mathrm{~g}$ per animal. The probiotic «Lactoamilovorin-SP» was also added at a dose of $10 \mathrm{~g}$ per animal during the first 30 days of life. The study showed that bifidobacteria and lactobacilli increased 2,7 and 2,6 fold, respectively. E. Coli bacteria rose 1,6 fold, Candida species fell 1,6 fold.

(C) Андреева А.В., Султангазин Г.М., Алтынбеков О.М.

УДК 619:616-002.4:636.2.055.8

DOI: $10.31563 / 1684-7628-2020-56-4-81-86$

В.В. Гимранов, И.Т. Гиниятуллин, А.И. Мирзин

\section{ВЛИЯНИЕ СУБТИЛИНОВОЙ МАЗИ НА ГЕМАТОЛОГИЧЕСКИЕ ПОКАЗАТЕЛИ У КОРОВ ПРИ ЗАЖИВЛЕНИИ ГНОЙНО-НЕКРОТИЧЕСКИХ ПРОЦЕССОВ}

Ключевые слова: пробиотики; гнойно-некротический; пальцы; коровы; кровь.

Введение. В условиях современного промышленного молочного животноводства заболевания конечностей являются одной из наиболее распространенных патологий животных дойного стада. Экономические потери от этих заболеваний значительны и складываются из снижения продуктивности коров, преждевременной выбраковки, затрат на лечение и профи- 
лактику болезней копыт (Семенов В.Г. и соавт., 2016; Галимзянов И.Г. и соавт., 2017; Гимранов В.В. и соавт., 2019; Коваленко А.М. и соавт., 2017; Evans N.J. et al., 2016; Jacobs C. et al., 2018). Причинами развития гнойно-некротических болезней у животных являются нарушение зоогигиенических условий содержания, кормления, недостаток моциона при отсутствии пастбищного содержания, несвоевременная расчистка и обрезка копытец, неиспользование ножных ванн (Evans N.J. et al., 2016). Лечение этих болезней требует комплексного и многопланового подхода (Plummer P.J., 2017). Все больные животные подвергаются индивидуальному лечению, в первую очередь проводятся расчистка и обрезка копытец и первичная хирургическая обработка патологического участка, для местного применения назначают антибиотики и сульфаниламидные препараты, сложные бактериоскопические порошки с салициловой кислотой, медьсодержащие и другие антисептические препараты, их применяют в виде присыпок, паст, мазей с использованием различных перевязочных материалов, в том числе новых, на основе полимеров, к которым относятся гидроколлоиды, альгинаты, гидрогели, полиуретан, коллаген, хитозан, пектин и гиалуроновая кислота (Capion N. et al., 2018; Apley M.D., 2015). В последнее время наряду с уже используемыми препаратами для лечения пальцевых дерматитов применяют пробиотики, вводимые животным перорально и местно. При даче их животным внутрь они обеспечивают полноценное функционирование пищеварительной, гормональной и иммунной систем организма, оказывают противоспалительное действие, улучшают регенеративные процессы. При местном применении пробиотиков для лечения пальцевых дерматитов они оказывают антимикробное, противоспалительное действие, стимулируют репаративные процессы и ускоряют заживление (Гимранов В.В. и соавт., 2019; Coman M.M. et al., 2020; Fijan S. et al., 2019).

Цель исследований - выявить влияние субтилиновой мази на заживление гнойно-некротических процессов в области пальцев у коров. Субтилиновая мазь содержит: действующее вещество Биосептин (Bacillus subtilis и Bacillus licheninformis) - $10 \%$; вспомогательные компоненты (аэросил - 10 \%, ПЭГ 1500 - 40 \%, ПЭГ $400-40 \%)$.

Материалы и методы. Исследования проводились на коровах черно-пестрой породы, было создано две группы животных (n-10), первая группа животных - здоровые коровы, вторая группа - коровы с гнойно-некротическими процессами в области пальцев. Для сравнительного анализа полученных данных кровь брали у здо- ровых коров; у больных коров взятие крови осуществляли до проведения лечения и через 10 дней после начала лечения. У всех больных коров проводили первичную хирургическую обработку некротических процессов и применяли марлевую повязку с Субтилиновой мазью. Смену повязки с использованием Субтилиновой мази проводили на 5 день после первичной обработки. Для полного выздоровления животных двух перевязок было достаточно.

Результаты исследований. Проведенными исследованиями у здоровых и больных коров с гнойно-некротическими процессами в области пальцев установлено (таблица 1), что содержание лейкоцитов в крови у здоровых коров составляет 6,09 \pm 0,13 тыс/мкл, у больных коров этот показатель составляет 9,28 \pm 0,7 тыс/мкл, что указывает на повышенное содержание лейкоцитов у больных коров, по сравнению со здоровыми, это повышение составляет 53,38 \%. Через 10 дней после лечения у больных коров количество лейкоцитов достоверно снизилось на 24,03 \% по сравнению с показателями до лечения и их уровень составил 7,05 \pm 0,34 тыс/мкл.

Количество лимфоцитов у здоровых коров составляло 4,08 \pm 0,08 тыс/мкл, у больных коров с гнойно-некротическими процессами в области пальцев уровень лимфоцитов был увеличен на $46,81 \%$ и составлял 5,99 $\pm 0,4$ тыс/мкл. Через 10 дней после лечения количество лимфоцитов у больных коров по сравнению с показателями до лечения снизилось с 5,99 $\pm 0,4$ тыс/мкл до $4,17 \pm 0,10$ тыс/мкл, уровень снижения составил $30,38 \%$.

Уровень показателя моноциты/эозинофилы у здоровых коров составил 0,43 \pm 0,02 тыс/мкл, у больных коров с гнойно-некротическими процессами в области пальцев этот показатель был значительно выше и составил 0,71 \pm 0,06 \% тыс/мкл, превышение составляет 65,12 \%. Через 10 дней после лечения этот показатель также незначительно вырос до 0,73 \pm 0,11 тыс/мкл или на 2,82 \% по сравнению с исходным значением.

Количественный показатель гранулоцитов в крови у здоровых коров составил 1,58 $\pm 0,1$ тыс/ мкл, у больных коров этот показатель был значительно выше: 2,60 \pm 0,27 тыс/мкл, превышение составило 64,56 \%, через 10 дней после лечения у больных коров по сравнению с показателями до лечения уровень гранулоцитов снизился на $21,15 \%$, и значение показателя составило 2,05 $\pm 0,11$ тыс/мкл.

Показатель \% лимфоцитов у здоровых коров составил $67,02 \pm 1,34 \%$ у у больных коров с гнойно-некротическими процессами в области пальцев этот показатель был на 0,42 \% ниже по сравнению с здоровыми коровами, а через 10 дней после лечения \% лимфоцитов в крови сни- 
зился на 1,88 \% по сравнению с показателями до лечения и составил $65,5 \pm 0,94 \%$.

Уровень \% моноцитов/эозинофилов у здоровых коров составил 6,75 \pm 0,34 \%, у больных коров с гнойно-некротическими процессами в об- ласти пальцев этот показатель был ниже на $5,19 \%$ и составил $6,40 \pm 0,33 \%$, а через 10 дней после лечения показатель \% моноцитов/эозинофилов был ниже по сравнению с показателями до лечения на 12,19 \% и составил 5,62 \pm 0,28 \%.

Таблица 1 Гематологические показатели у здоровых коров у больных коров до лечения и через 10 дней после начала лечения

\begin{tabular}{|c|c|c|c|}
\hline \multirow[b]{2}{*}{ Показатель } & \multicolumn{3}{|c|}{ Группа коров } \\
\hline & $\begin{array}{c}\text { Здоровые } \\
\text { коровы }\end{array}$ & $\begin{array}{c}\text { Больные } \\
\text { коровы }\end{array}$ & $\begin{array}{l}\text { Больные коровы через } \\
10 \text { дней после лечения }\end{array}$ \\
\hline WBC - лейкоциты (тыс/мкл) & $6,09 \pm 0,13$ & $9,28 \pm 0,7^{*}$ & $7,05 \pm 0,34 *$ \\
\hline LYM - лимфоциты (тыс/мкл) & $4,08 \pm 0,08$ & $5,99 \pm 0,4^{*}$ & $4,17 \pm 0,10^{*}$ \\
\hline MID - моноциты/эозинофилы (тыс/мкл) & $0,43 \pm 0,02$ & $0,71 \pm 0,06^{*}$ & $0,73 \pm 0,11$ \\
\hline GRA - гранулоциты (тыс/мкл) & $1,58 \pm 0,1$ & $2,60 \pm 0,27 *$ & $2,05 \pm 0,11 *$ \\
\hline $\mathbf{L Y}$ - \% лимфоцитов & $67,02 \pm 1,34$ & $66,72 \pm 1,19$ & $65,5 \pm 0,94$ \\
\hline МІ - \% моноцитов/эозинофилов & $6,75 \pm 0,34$ & $6,40 \pm 0,33$ & $5,62 \pm 0,28 *$ \\
\hline GR - \% гранулоцитов & $25,84 \pm 1,36$ & $26,39 \pm 1,01$ & $28,88 \pm 0,94 *$ \\
\hline RBC - эритроциты (млн/мкл) & $6,78 \pm 0,14$ & $7,85 \pm 0,28 *$ & $7,89 \pm 0,23$ \\
\hline HGB - гемоглобин (г/л) & $130,9 \pm 2,30$ & $136,70 \pm 1,87$ & $134,9 \pm 1,35$ \\
\hline НСТ - гематокрит (\%) & $43,33 \pm 0,29$ & $41,77 \pm 0,39$ & $41,86 \pm 0,40$ \\
\hline MCV - средний объем эритроцитов (фл) & $40,50 \pm 1,63$ & $43,89 \pm 0,83 *$ & $44,30 \pm 0,54$ \\
\hline МСН - среднее содержание гемоглобина в эритроците (пг) & $13,9 \pm 0,00$ & $14,46 \pm 0,21$ & $14,05 \pm 0,04$ \\
\hline МСНС - средняя концентрация гемоглобина в эритроцитах (г/л) & $391,00 \pm 0,00$ & $373,0 \pm 2,95$ & $357,7 \pm 6,32$ \\
\hline PLT - тромбоциты (тыс/мкл) & $267,0 \pm 10,23$ & $359,8 \pm 20,64 *$ & $441,7 \pm 26,07 *$ \\
\hline
\end{tabular}

Количественный показатель \% гранулоцитов у здоровых коров составил $25,84 \pm 1,36 \%$, у коров с гнойно-некротическими процессами в области пальцев это значение по сравнению с здоровыми коровами было выше на 2,12\% и составило 26,39 $\pm 1,01 \%$. Через 10 дней после лечения значение \% гранулоцитов крови у больных коров повысилось на 9,43\% по сравнению с показателями до лечения на 9,43\% и составило $28,88 \pm 0,94 \%$.

Количество эритроцитов у здоровых коров составило $6,78 \pm 0,14$ млн/мкл, у больных коров с гнойно-некротическими процессами в области пальцев количество эритроцитов по сравнению с здоровыми коровами было выше на 15,78 \%, в цифровом значении этот показатель составил 7,85 \pm 0,28 млн/мкл. Через 10 дней после лечения количество эритроцитов у больных коров по сравнению с исходным практически не изменилось: 7,89 $\pm 0,23$ млн/мкл.

У здоровых коров уровень гемоглобина составил 130,9 $\pm 2,30$ г/л, у больных коров количество гемоглобина по сравнению с здоровыми животными было выше, и этот показатель составил $136,70 \pm 1,87$ г/л, превышение - 4,43 \%. Через 10 дней после лечения уровень гемоглобина у больных коров снизился по сравнению с показателями до лечения, в цифровом значении этот показатель составил 134,9 \pm 1,35 г/л, таким образом, снижение составило 1,32 \%.

Процент гематокрита в крови у здоровых коров составил 43,33 \pm 0,29\%, у больных коров его уровень был ниже на $1 \%$, цифровое значение его составило $41,77 \pm 0,39 \%$. Через 10 дней после лечения уровень гематокрита у больных ко- ров практически не изменился по сравнению с показателями до лечения.

Средний объем эритроцитов у здоровых коров составлял 40,50 \pm 1,63 фл., у больных коров средний объем эритроцитов был выше, в цифровом значении это составило 43,89 $\pm 0,83$ фл., что показывает достоверное превышение на 8,37 \%. Через 10 дней после лечения средний объем эритроцитов у больных коров практически не изменился по сравнению с показателями до лечения.

Среднее содержание гемоглобина в эритроците у здоровых коров составило 13,9 \pm 0,00 пг., у больных коров этот показатель по сравнению с здоровыми был выше на 4,03\%, в цифровом значении этот показатель составил 14,46 $\pm 0,21$ пг. Через 10 дней после лечения у больных коров этот показатель практически не изменился по сравнению с показателями до лечения.

Средняя концентрация гемоглобина в эритроцитах у здоровых коров составила 391,00 \pm 0,00 г/л, у больных коров - ниже на 4,6 \%, в цифровом значении это составило $373,0 \pm 2,95$ г/л. У больных коров после начала лечения средняя концентрация гемоглобина в эритроцитах продолжала снижаться и через 10 дней этот уровень составил $357,7 \pm 6,32$ г/л, таким образом, снижение составило 4,29\%.

Количество тромбоцитов у здоровых коров составило 267,0 \pm 10,23 тыс/мкл. У больных коров уровень тромбоцитов в крови по сравнению с здоровыми коровами был значительно выше: $359,8 \pm 20,64$ тыс/мкл., превышение составило 34,76 \%. Через 10 дней после лечения у больных коров количество тромбоцитов повысилось на 22,76 \% по сравнению с их количеством до ле- 
чения, в цифровом значении это составило $441,7 \pm 26,07$ тыс/мкл.

Таким образом, наши исследования показали существенные различия в показателях крови у здоровых и больных коров и их показателях после лечения. У больных коров измене- ния в крови связаны с наличием гнойно-некротического процесса. В процессе лечения с использованием субтилиновой мази на фоне заживления отмечается тенденция нормализации гематологического профиля у больных животных.

\section{Библиографический список}

1. Галимзянов, И.Г., Лечение инфекционного пальцевого дерматита у крупного рогатого скота [Текст] / И.Г. Галимзянов, О.И. Шоркина, P.Р. Шафигуллин // Ученые записки КГАВМ им. Н.Э. Баумана. 2017. № 229 (I). С. 9-13.

2. Гимранов, В.В. Особенности и способы применения пробиотиков при гнойно-некротических процессах у крупного рогатого скота [Текст] / В.В. Гимранов, И.Т. Гиниятуллин // Актуальные вопросы и пути их решения в ветеринарной хирургии. Материалы Международной научно-практической конференции, посвященной 80-летию со дня рождения профессора Э.И. Веремея. 2019. С. 20-21.

3. Гимранов, В.В. Применение пробиотиков при гнойно-некротических процессах в области пальцев у крупного рогатого скота [Текст] / В.В. Гимранов, И.Т. Гиниятуллин, Р.Р. Вахитов // Актуальные проблемы ветеринарной медицины, зоотехнии и биотехнологии. Сборник научных трудов Международной учебно-методической и научно-практической конференции, посвященной 100-летию со дня основания ФГБОУ ВО МГАВМиБ - МВА имени К.И. Скрябина. Федеральное государственное бюджетное образовательное учреждение высшего образования «Московская государственная академия ветеринарной медицины и биотехнологии - MBA имени К.И. Скрябина». 2019. С. 86-88.

4. Коваленко, А.М. Применение «Ортолека» при лечении коров с пальцевым дерматитом [Текст] / А.М. Коваленко, И.В. Явников, Н.Н. Шпоганяч // Актуальные вопросы сельскохозяйственной биологии. 2017. № 3 (5). С. 24-28.

5. Семенов, В.Г. Система профилактики хромоты и терапии болезней у коров [Текст]/ В.Г. Семенов, А.В. Чичулин // Ученые записки КГАВМ им. Н.Э. Баумана. 2016. № 226 (II). C. $147-150$.

6. Apley M.D. Clinical Evidence for Individual Animal Therapy for Papillomatous Digital Der- matitis (Hairy Heel Wart) and Infectious Bovine Pododermatitis (Foot Rot). J. Veterinary Clinics of North America - Food Animal Practice. 2015. Tом: 31. Выпуск 1. Стр. 81-85.

7. Capion N., Thamsborg S.M., Enevoldsen C. Prevalence of foot lesions in Danish Holstein cows. J. Veterinary Record. 2008. Том 163. Выпуск 3. Стр. 80-86.

8. Capion N., Larsson E.K., Nielsen O.L. A clinical and histopathological comparison of the effectiveness of salicylic acid to a compound of inorganic acids for the treatment of digital dermatitis in cattle. J. of Dairy Science. 2018. Том 101. Выпуск 2. Стр. 1325-1333.

9. Coman M.M., Mazzotti L., Silvi S., Scalise A., Orpianesi C., Cresci A., Verdenelli M.C. Antimicrobial activity of SYNBIO probiotic formulation in pathogens isolated from chronic ulcerative lesions: in vitro studies. Journal of Applied Microbiology. 2020. Том 128. Выпуск 2. Стр. 584-597.

10. Evans N.J., Murray R.D., Carter S.D. Bovine digital dermatitis: Current concepts from laboratory to farm. Veterinary Journal. 2016. Tом 211. Стр. 3-13.

11. Fijan S., Frauwallner A., Langerholc T., Krebs B., Haar ter J.A., Jessica A., Heschl A., Turk D.M., Rogelj I. Efficacy of Using Probiotics with Antagonistic Activity against Pathogens of Wound Infections: An Integrative Review of Literature. J. Biomed Research International. 2019. Tом 2019. Номер статьи 7585486.

12. Jacobs C., Orsel K., Mason S., Barkema H.W. Comparison of effects of routine topical treatments in the milking parlor on digital dermatitis lesions. J. of Dairy Science. 2018. Том 101. Выпуск 6. Стр. 5255-5266.

13. Plummer P.J., Krull A. Clinical Perspectives of Digital Dermatitis in Dairy and Beef Cattle. J. Veterinary Clinics of North America - Food Animal Practice. 2017. Том 33. Выпуск 2. Стр. 165168.

\section{Сведения об авторах}

1. Гимранов Валиян Валиуллович, доктор ветеринарных наук, профессор, профессор кафедры морфологии, патологии, фармации и незаразных болезней, ФГБОУ ВО Башкирский ГАУ, г. Уфа, ул. 50-летия Октября, 34, тел.: +7 (347) 228-08-57, e-mail: gim-val@mail.ru.

2. Гиниятуллин Ильшат Талгатович, аспирант кафедры морфологии, патологии, фармации незаразных болезней, ФГБОУ ВО Башкирский ГАУ, г. Уфа, 50-летия Октября, 34. 
3. Мирзин Азамат Ильшатович, аспирант кафедры морфологии, патологии, фармации незаразных болезней, ФГБОУ ВО Башкирский ГАУ, г. Уфа, 50-летия Октября, 34.

Проведенными исследованиями установлено, что у здоровых и больных коров с гнойнонекротическими процессами в области пальцев имеются существенные различия в показателях крови. Отмечено, что у больных коров по сравнению с здоровыми в крови достоверно увеличено количество лейкоцитов $(53,38 \%)$, лимфоцитов $(46,81 \%)$, эритроцитов $(15,78 \%)$, гранулоцитов $(64,56 \%)$, тромбоцитов $(34,76 \%)$, увеличен средний объем эритроцитов $(8,37 \%)$, повышен уровень моноциты/эозинофилы $(65,12 \%)$. Установлено, что двукратное применение перевязок с субтилиновой мазью с интервалом в пять дней способствует заживлению в течение 10 дней гнойно-некротических процессов в области пальцев у крупного рогатого скота. Проведенные исследования показали, что применение субтилиновой мази не требует радикального хирургического вмешательства, так как компоненты мази лизируют мертвые ткани, и этот процесс протекает атравматично, что в последующем способствует нормализации течения процессов гранулирования, эпидермизации и сокра- щает сроки заживления. Через десять дней после начала лечения на фоне заживления происходят изменения, позволяющие говорить о тенденции нормализации гематологического профиля у больных коров. Так после начала лечения через 10 дней в крови по сравнению с показателями до лечения у больных коров отмечается снижение количества лейкоцитов $(24,03 \%)$, лимфоцитов $(30,38 \%)$, гранулоцитов $(21,15 \%)$. В то же время проведенные нами исследования позволили установить, что достоверных изменений в крови у здоровых, больных коров до лечения и после лечения в таких показателях, как количество эритроцитов, гемоглобина, среднее содержание гемоглобина в эритроците, средняя концентрация гемоглобина в эритроцитах, \% лимфоцитов, не выявлено. Таким образом, проведенные исследования показали существенные различия в показателях крови у здоровых и больных коров, указывающие на наличие гнойного воспалительного процесса, а после лечения - на тенденцию нормализации гематологичского профиля у больных коров.

V. Gimranov, I. Giniyatullin, A. Mirsin

\title{
EFFECT OF SUBTILIN OINTMENT ON COWS' HEMATOLOGICAL PARAMETERS IN REGENERATION OF PURULENT-NECROTIC PROCESSES
}

\author{
Key words: probiotics; purulent-necrotic; cow's claws; cows; blood.
}

\section{Authors' personal details}

1. Valiyan Gimranov, Doctor of Veterinary Sciences, Professor, Professor of the Department of Morphology, Pathology, Pharmacy and Non-Infectious Diseases, Federal State Budgetary Educational Institution of Higher Education «Bashkir State Agrarian University», 450001, Ufa, 50-letiya Oktyabrya St., 34, phone: +7 (347) 228-08-57, e-mail: gim-val@mail.ru.

2. Ilshat Giniyatullin, Post-graduate student of the Department of Morphology, Pathology, Pharmacy of Non-Infectious Diseases, Federal State Budgetary Educational Institution of Higher Education «Bashkir State Agrarian University», 450001, Ufa, 50-letiya Oktyabrya St., 34.

3. Azamat Mirzin, Post-graduate student of the Department of Morphology, Pathology, Pharmacy of Non-Infectious Diseases, Federal State Budgetary Educational Institution of Higher Education «Bashkir State Agrarian University», 450001, Ufa, 50-letiya Oktyabrya St., 34.

The study has demonstrated that healthy cows and cows suffering from the claw area's purulentnecrotic processes have significant differences in blood parameters. In comparison to healthy cows sick cows have the increased number of leukocytes $(53,38 \%)$, lymphocytes $(46,81 \%)$, erythrocytes $(15,78 \%)$, granulocytes $(64,56 \%)$, platelets $(34,76 \%)$, increased average volume of red blood cells (of $8,37 \%$ ), increased levels of monocytes/eosinophils $(65,12 \%)$. The study has established that double dressing with Subtilin ointment applied at intervals of five days enables the cows' claw purulent-necrotic processes to regenerate within ten days. The study has shown that Subtilin ointment does not require radical surgical intervention since the ointment lyse dead tissue. The process is atraumatic and results in improved granulation and epidermization, shortening the regeneration time. Ten days after the treatment start, sick cows demonstrate changes in the blood. The changes denote that the sick cows' hematological parameters tend to improve. Compared with the values before the treat- 
ment, sick cows show a decrease in white blood cells $(24,03 \%)$, lymphocytes $(30,38 \%)$, granulocytes $(21,15 \%) 10$ days after the start of treatment. The study has revealed no reliable changes in such blood indices as red blood cells, hemoglobin, the average hemoglobin in red blood cells, the average concentration of hemoglobin in red blood cells, the

(C) Гимранов В.В., Гиниятуллин И.Т., Мирзин А.И. percentage of lymphocytes of both healthy and sick cows before and after the treatment. Thus, the study has shown significant differences in blood parameters in healthy and sick cows. The blood parameters can indicate a purulent inflammatory process; after the treatment, the values indicate that the sick cows' hematological profile improves.

УДК 619:636.4.033

DOI: 10.31563/1684-7628-2020-56-4-86-91

3.3. Ильясова, Р.Т. Маннапова

\section{МОРФОЛОГИЧЕСКИЕ ПОКАЗАТЕЛИ КРОВИ ПОРОСЯТ ПРИ КОМПЛЕКСНОЙ ТЕРАПИИ ДИСПЕПСИИ}

\section{Ключевые слова: свиноводство; поросята; кровь; диарея; терапия.}

Введение. В настоящее время к выбору и применению лекарственных средств для лечения и профилактики желудочно-кишечных болезней поросят предъявляются серьезные требования, вытекающие из необходимости бережного лечения и коррекции иммунного статуса и микробиоценоза кишечника. В нашей стране и за рубежом разработаны и широко применяются различные средства для лечения и профилактики нарушений работы желудочно-кишечного тракта молодняка сельскохозяйственных животных. Однако не все они обладают высокой терапевтической и экономической эффективностью и не лишены недостатков. Анализ литературных данных показывает, что в последние годы все больше создаются и внедряются различные препараты на основе фитопробиотических композиций, лактобактерий, микроэлементов, цеолитов, прополиса и других пробиотических добавок $[2,5,6]$.

Многочисленными исследованиями ряда отечественных и зарубежных авторов установлено, что болезни молодняка чаще возникают на фоне неблагоприятного воздействия на животных многочисленных технологических стрессфакторов, снижающих общую неспецифическую резистентность организма и сохранность поголовья [3, 7-10].

Наиболее перспективной отраслью является свиноводство, так как свиньи более скороспелые и многоплодные животные, позволяющие обеспечить продовольственную независимость страны. Однако выполнению этой задачи могут препятствовать различные заболевания, к числу которых относятся желудочно-кишечные болезни поросят в ранний постнатальный период. Они широко распространены во всех странах мира с развитым свиноводством, занимают ве- дущее место в патологии свиней и наносят огромный экономический ущерб $[1,4]$.

Целью исследований явилось изыскание эффективного метода лечения диспепсии поросят-сосунов и его влияние на морфологические показатели крови, динамику живой массы и сохранности поросят.

Материал и методы исследований. В производственных опытах было использовано 30 новорожденных поросят 5-дневного возраста, которых разделили на 3 группы по 10 голов в каждой.

Поросята с рождения до 23-25-дневного возраста находились на площадке опороса цеха воспроизводства (репродуктора) со свиноматкой. С 23-25- до 73-75-дневного возраста поросята содержатся в цехе доращивания. С 73-75до 175-дневного возраста свиньи находятся в цехе откорма. С 176-дневного возраста проводится реализация живого поголовья.

Животные I группы были контрольные клинически здоровые; поросята II и III групп опытные, больные.

Всем животным для профилактики железодефицитной анемии вводили железосодержащий лекарственный препарат Урсоферран однократно по 1 мл на третьи сутки жизни внутримышечно в область шеи.

Животным I группы с профилактической целью вводили комбинированный витаминный комплекс «Элеовит» двукратно с интервалом 21 сутки (в пяти- и 26-дневном возрасте) внутримышечно по 0,5 мл в область шеи.

Животным II группы применяли антибиотик широкого спектра действия «Энрофлон» 5 \%ный для инъекций внутримышечно в область шеи по 1 мл/гол массой до трех кг с пятидневного возраста в течение пяти дней. «Элеовит» применяли с лечебной целью внутримышечно 